\title{
Rethinking Androcentric Representations of Women in African Literature
}

\section{Omar Sougou}

\section{(2) OpenEdition \\ 1 Journals}

Electronic version

URL: https://journals.openedition.org/ces/8429

DOI: $10.4000 /$ ces.8429

ISSN: 2534-6695

\section{Publisher}

SEPC (Société d'études des pays du Commonwealth)

\section{Printed version}

Date of publication: 1 April 2010

Number of pages: 87-97

ISSN: 2270-0633

\section{Electronic reference}

Omar Sougou, "Rethinking Androcentric Representations of Women in African Literature",

Commonwealth Essays and Studies [Online], 32.2 | 2010, Online since 18 December 2021, connection on 31 January 2022. URL: http://journals.openedition.org/ces/8429; DOI: https://doi.org/10.4000/ces. 8429

\section{(c) (i) $\odot$}

Commonwealth Essays and Studies is licensed under a Licence Creative Commons Attribution - Pas d'Utilisation Commerciale - Pas de Modification 4.0 International. 


\section{Rethinking Androcentric Representations of Women in African Literature}

The representation of women in fictional discourse still remains an area of live interest in African literary criticism. There has been a sustained focus in the flawed portraiture of women in male writing, yet more and more male creative writers are striving to draw images of women from an increasingly gender sensitive perspective. They endeavour to depict women in positive roles and emphasize their agency in society. Similarly, more male critics are venturing into the female creative space while being mindful not only of the insider/outsider location paradigm but also of the critical attention of their female colleagues. The developing critical interaction between female and male writers and critics significantly contributes to the growth of African literature. This paper embarks on a study that leans on the revisionist critical trend in an attempt to examine the portrait of African women in novels particularly by Ousmane Sembene and Ngugi wa Thiong'o that show them as initiators and actors in the struggle for the community's political and social welfare.

$\mathrm{W}$

ith the advent of feminist criticism, the interrogation of male writers' treatment of women in literature has become a major field of study for purposes of challenging androcentric representations of women. In Africa the same trend has marked the female-centred critical discourse on literature, whether from a feminist or womanist perspective. Likewise, in the last twenty years, significant texts by women critics and creative writers have addressed the issue in various forms and from different viewpoints. Although what has been considered as "image of women criticism" in feminist literary studies is no longer but a stage in critical theory, the representation of women in fictional and academic discourse still remains an area of live interest. In African literature, the focus has been intently on the depiction of women in male writing. Its critics mainly concentrate on texts that present a biased picture of womanhood. Yet, there are writers who endeavour to depict women in positive roles and emphasize their agency in society as much as the limits of experience allow it. Such limits are pinpointed by female critics; inside knowledge seems crucial to the appraisal of males' portrayal of women. But it remains to be seen whether one has to keep away from the unknown, because one is not an insider. Epistemology would not have done so well if researchers had remained in the confines of known areas. Consequently, it would be useful to study the changing image of African women in novels written by men which offer a different picture of female characters, one in which they are initiators and actors.

In The Sociology of Urban African Women's Image in African Literature, Kenneth Little surveys thirty-five male novelists' works and concludes that female 
characters are portrayed as girl-friends, good-time girls, wives, free-women, mothers, workers, political women, courtesans, and prostitutes. African women mainly operate as appendices to men; as much can also be gathered from Lloyd Brown's Women Writers in Black Africa. At the close of his analysis, Little wonders why it is so difficult to find as a central character: a female doctor, lawyer, highranking civil servant, director of public service; whereas such persons exist in real life. He adds: "Surely it is time for this fact to be signalised in the literature of the novelist in particular. Until this is done, the charge of male chauvinism may be difficult to rebut" (157-158). He calls upon female writers to meet such a challenge, which they have done so actively in the last two decades. Before Little and Brown, a female critic, Eleanor Watchel, stressed the misrepresentation of women. Watchel's study concerns itself with the image of women and "the framing and manipulation of female stereotypes" in Kenyan fiction, but her observations can apply to African literature in general. The current feministoriented criticism bears witness to this, judging by the sundry publications on the subject. The works contain essays that address the issue of female representation, and voice sustained criticism of the male practice that consists in relegating the female subjects to the periphery, while male ones occupy the centre. As Carole B. Davies writes:

Literature, because it mirrors and/or recreates social, historical and economic realities, is one of the channels through which negative attitudes and stereotypes of women are perpetuated, even created. Modern African literature too, because it has adopted many of the Western patriarchal modes of thoughts and expression, often conveys some of these biased attitudes to which we refer. (75)

Although the charges of flawed representation are valid for most of the literature, it seems proper to examine not just the negative picture of the African woman drawn by some African male novelists, but to chart the attempt of those who have accorded her a significant place and role in their writings. It will be shown in this discussion that a category of writers, namely Ousmane Sembene and Ngugi wa Thiong'o, have consistently striven to avoid the pitfalls of stereotyping. The adopted approach in this study sides with the revisionist critical outlook many female critics call for, and which is articulated by Davies thus:

Revisionist criticism of African literature then has as one of its tasks the truthful assessment of the literary image of women. It must therefore approach already well criticized texts/authors from a critical posture which seeks to reveal and thereby correct some of these attitudes and in so doing challenge authors to project a complete picture of African social reality. (75)

Ousmane Sembene and Ngugi wa Thiong'o are known to have depicted women as prime movers in their novels. They, in the words of Davies, have already begun the process of using their artistic "power to create new realities; to represent male-female relationships and the role of women as they have been 
in the past and might be in the future: women as neither victors nor victims but partners in the struggle" (Davies 86). The work of these novelists addressing respectively a francophone and an anglophone audience shows a representation of the African woman altogether different from what Florence Stratton considers as "the double bind of calcification or catalepsy [that] is enacted by men writers in their texts: the identification of women with 'petrified' cultural traditions and the allocation to male characters or narrators the role of regaining control over the historical development of their societies" (Stratton 8). Sembene is renowned for creating female characters that seize the right to act on their own impulse and shoulder social roles otherwise denied them. Penda, in God's Bits of Wood, typifies such women; she is independent, resolute and lucid in her choices. Viewing marriage as a trap, she enjoys sexual freedom, for which the community labels her a prostitute. Female critics regard her depiction as a fair representation of women in fiction, a hallmark of Sembene's writings that Karen Smiley-Wallace rightly conveys:

$[\mathrm{He}]$ is noted for his finely chiseled portraits of females as real, palpable individuals. By creating women figures who do not merely represent shadows of the male figure, nor echoes of the male voice, Sembene's works reflect the complexities of a changing Africa. He departs measurably from the rather static image carved by Sadji, and renders the female character a dynamic being, who must constantly struggle to redefine her perception of self in the developing African continent and in the world. (64-65)

In Little's typology Penda appears in the chapter devoted to 'free women' but he deals with her in that which is entitled 'Political Women and Workers'. For she demonstrates superior qualities which cause her to be co-opted on to the leadership of the women's action group during the railway workers' strike of October 1947-March 1948. She takes the initiative in organizing the women's fifty mile protest march to the capital city and functions as a pivotal character that is always at the forefront in the episodes in which she appears.

Sembene states in the foreword to another novel, L'harmattan, that he does not like heroes because they die young. Penda being shot dead by one of the soldiers picketing the road to stop the marchers may be therefore regarded as the real hero of this novel. Furthermore, her treatment falls into the following definition of female "hero" that Berenice Fisher propounds in Kramarae and Treichler's $A$ Feminist Dictionary:

Rather than one who is superhuman and above the rest of society, it is a woman who shares our conflicts and struggles in a contradictory world. "She shows us how to struggle more successfully.... The genuine hero helps her friends and comrades by teaching them directly or indirectly what she has learnt from experience, and how she has applied theoretical and practical knowledge to specific situations." 
Penda is neither a professional woman, nor a theoretician, but as a commoner, she fulfils her role in society and attains self-realization in what the dedicatory note of God's Bits of Wood terms the "struggle for a better way of life". In his representation of women, Sembene spurns the binary constructions that Mineke Schipper views as "stereotypes of good (= the traditional loving mother) and the bad (= the modern, evil, vicious girl)." She posits: "Sembène Ousmane is a significant example of emancipated thinking: he mercilessly highlights women's inequality and criticizes their resignation to their fate. He also shows the role that women should play in the development of society" (Schipper 45) .

L'harmattan is another significant novel by Sembene in which a young woman plays an important role in the political action during the stride of Africa to independence, yet it has not received as much critical attention as God's Bits of Wood. In L'harmattan, Sembene introduces a female character, Tioumbé, who, like Penda, is involved in the people's struggle against colonial oppression. Tioumbé is active in the Pan-African movement campaigning for the total independence of French colonies in West Africa, a momentous historical event. The colonies were to decide through the 1958 referendum whether they wished to be granted independence within the framework of the French Communauté or attain immediate independence without it.

Unlike Penda, Tioumbé is a teacher and a leader of men and women. Her public fight for the political independence of the French colonies of Africa parallels her domestic combat against patriarchy, which in return is metonymical of the contradiction between the colonized and the colonizer. Her strained relations with her father reflect the prevailing social and political tension in the land at that time. Her father, a catechumen with a mission to spread his religion among his people and also bring them to cast a "Yes" vote for the Communauté, is distraught by the involvement of his daughter in the leadership of the local Marxist group engaged in the united front campaigning for a "No" vote, the way to total independence. Tioumbé is part of the conscious urge for liberation that pervades and upsets the social order, which the narrator renders.

The issue of political independence deepens the rift between fathers and children. Unable to see beyond the enticing sacks of rice generously bestowed on them in exchange for their suffrage, the older and conservative generation acquiesces in the French government's recommendation to vote "Yes" for the Communauté. Thus, Tioumbés involvement in the "No" campaign is synonymous with iconoclasm; she opposes everything her father's camp stands for, just as she and the militant group challenge the French colonial government. She openly rejects religion and remains unrepentant. The fatherdaughter moral battle culminates in a physical confrontation over Tioumbés ballot card, which her father seizes. Like many other family heads, he intends to make all the members of his family vote "Yes." Unlike the first time her father flogged her; she fights back and repossesses the card, which is an abomination for the community. Even her mother resents her act; despite her being 
constantly humiliated by her husband, she stands by him against her daughter. Tioumbés rebellion against the "law of the father" is inscribed in the colonizer/ colonized dynamics; it concentrates the struggle against the colluding power structures of patriarchy and colonialism towards a new order. The shift in the paradigms that has governed relationships for centuries clearly appears in the new power relations and interests. Change relentlessly claims its way, and Tioumbé, aspiring to progress and independence, "moves with the tide." The independence that African countries demand tallies with women's wish for individuation stated in their resolute commitment to the struggle. The stalwart figure of Tioumbé exemplifies a positive portraiture of African womanhood in male writing. In creating her, Sembene pays homage to the women who fought for independence side by side with men. Putting her in the vanguard of the movement is tantamount to acknowledging Pan-African female activists. She enjoys respect and trust from her male comrades, and she is said to be politically more seasoned than her fiancé. She remains the one who uplifts him after the blow dealt to the movement with the victory of "Yes" everywhere in the French colonies of their part of Africa, except in Guinea. Davies regards Sembene's creation of his character Tioumbé as "a positive image ... one that is in tune with African historical realities and does not stereotype or limit women into postures of dependence or submergence. Instead, it searches for more accurate portrayals and ones which suggest the possibility of transcendence" (Davies 15).

The writings of Ngugi present similarities with those of Sembene; their outlook and concerns are very close. Both of them regard prostitutes not as outcasts or evil people but as victims who become liberated individuals willing to join in their society's actions against injustice. They are aware of what Ogunyemi emphasizes, that is, that "the literature is phallic, dominated as it is by male writers and male critics who deal almost exclusively with male characters and male concerns, naturally aimed at a predominantly male audience" (60), and they try to remedy this.

Wanja in Ngugi's Petals of Blood has many features in common with Penda in Sembene's God's Bits of Wood. Even beyond these characters, the two novels have strong intertextual bonds. These two young female characters are in control of their lives, but they enjoy their freedom all the while maintaining close ties with their communities. Wanja is attached to the rural life of Ilmorog despite her escapes to the city. She is torn between a wish to turn her back on her life as a prostitute and a craving for the sense of power over men such a life gives her. She hankers after a Queen-bee image reminiscent of Simi, the irresistible courtesan who toys with her male votaries in Soyinka's The Interpreters. Wanja's immersion in the struggle of Ilmorog people turns into a personal pursuit that finds roots in her teenage life. She seeks to avenge herself on the VIP who seduced her in her school days and left her with a child she threw into a drain. The victimized Wanja epitomizes the fate of young girls and women abused by the rising native comprador bourgeoisie that is the target of Ngugi. She finally sets up as a courtesan 
and brothel keeper, and does not readily follow the revolutionary path on which Karega means to draw her, even though she is an active participant in the protest march against the system. There lies a significant difference between Wanja and Penda, the latter seizes the opportunity of the railway workers' industrial action to assert herself in a different way.

However, with Wariinga, in Devil on the Cross, Ngugi seems to revise the Wanja image of victimhood and pushes this new character further into the social struggle. Wariinga's life story somewhat echoes Wanja's as they have both been victims of older men's concupiscence. Wariinga's efforts to lead a decent honest life working as a secretary are thwarted by a lascivious employer who harasses her sexually and dismisses her from her job because she refuses to yield. Rescued from suicide, she discovers the real face of the world she lives in by attending a gathering of thieves. The event is a symbolical, satirical representation of Kenyan nouveaux riches that are fronting for international capital. Ngugi allegorically dramatizes the eye-opening effect of this experience on Wariinga through the interplay of good and evil temptations out of which she undergoes a thorough transformation and becomes more confident and proud of her natural self. New awareness transforms her into a clear-sighted woman able to discard the artificial cultural imports which had enslaved her for some time. Wariinga thus appears as a potent agent of the social and cultural revolution that Ngugi considers mandatory for any kind of liberation. In her development, she goes from an attitude that privileges "the personal is the political" principle to one that puts forward the Marxist strategy Ngugi advocates in this novel. ${ }^{1}$ Ngugi notably wrote in Detained: "because women are the most oppressed and exploited section of the working class, I would create a picture of a strong determined woman with a will to resist and to struggle against the conditions of her present being" (10). In his commitment to changing women's image by creating a sturdy female character, Ngugi makes Wariinga execute her wrong-doers. As in Petals of Blood, the neocolonial agents are disposed of, this time by the hand of the heroine: harbinger of new times and relations. The death of the victimizers is meant to be seen as the elimination of the class of the exploiters by that of the down-trodden whom Wariinga represents. She is part of the prism through which the novelist's chosen class position is refracted. As Micere Mugo observes:

We have only a very few writers who have chosen to side with the oppressed majority, who have actually taken a clear ideological position in which they are going to use their writing as a weapon in the struggle for liberation [...] The kind of writer that I have a lot of time and respect for is a writer like the late Alex La

1. Catharine A. MacKinnon explains that "The personal as political ... means that women's distinctive experience as women occurs within that sphere that has been socially lived as the personal-private, emotional, interiorized, particular, individuated, intimate - so that what it is to know the politics of women's situation is to know women's lives.' MacKinnon as quoted in Kramarae 233). 
Guma. I admire the fact that his writing was not only talking about struggle, but he was really a part and parcel of the struggle in South Africa. I admire somebody like Ngugi wa Thiong'o, whose example and position in life has demonstrated his commitment to the struggle of the Kenyan people. I admire somebody like Sembene Ousmane. This kind of writer I want to identify with. (Mugo 96)

The role older women play in Ngugi's works is noteworthy; they are everpresent and active in the life and struggle of their community. They are usually highly regarded figures who participated in the Mau-Mau movement, such as Wambui in A Grain of Wheat. She is so important in her community that she has been chosen to preside over the trial of Mugo, the traitor. She is important in an analogous way for the novel because she is the medium through which the post Mau-Mau is assessed: she "was lost in a solid consciousness of a terrible anticlimax to her activities in the fight for freedom" (275). Wambui's intention to sweep the room and her exclamation: "how dirt can so quickly collect in a clean hut!" (276) are figurative references to the situation in which the country finds itself soon after independence. The fact that she does not rise to do anything suggests dejection in the face of the anti-climax she witnesses. In return, the reader of Matigari recognizes Wambui in the old woman whom Matigari meets in his quest for "truth and justice." She is busy collecting rubbish and she significantly tells him: "let me continue sweeping this dirt that has quickly accumulated in our country!" (Matigari 88).

The old Nyakinyua in Petals of Blood similarly bears witness to a period in which "dirt" kept collecting in the guise of faithless and unscrupulous politicians of the neo-colonial era. Nyakinyua is the heartbeat of Ilmorog, which she fights to preserve from covetous politicians. Despite old age, she takes part in the protest journey to the city and remains the focus of political and cultural resistance so long as she remains alive in the narrative. Wanja finds solace by her side, and Karega, the young revolutionary, learns from her stories. In a traditional verbal contest, Nyakinyua challenges the audience with this riddle: "If a thread was broken to whom were the pieces thrown to mend them into a new thread?" Somebody replies, "When an old thread was broken it was time for the whole people to change to another tune altogether, and spin a new and stronger thread" (Petals 209). The metaphorical thread is the disruptive economic and social dispensation that is to the people's disadvantage. The solution lies in a new co-ordinated struggle to build a new society, as the reply stipulates, a message which Ngugi reiterates in Devil on the Cross and Matigari. The new society is to be built by the oppressed workers, peasants, women, and committed intellectuals who take the initiative to attack the foreign capitalists and the neocolonial native ruling elite in Devil on the Cross, a novel in which Wangari plays a significant part in the combat against the exploiters.

Wangari is emblematic of the transition between Wambui, Nyakinyua and Wariinga. She took part in the fight for independence and is fit enough to join 
those who "have started to organize to oppose the neocolonial comprador ruling class" that confiscated the fruit of the people's endeavour (Ngugi, Barrel of a Pen, 3). As she said: "I, the Wangari you see before you, was a small girl then. But these legs have carried many bullets and many guns to our fighters in the forest ... And I was never afraid, even when I slipped through the lines of the enemy and their homeguard allies" (Devil on the Cross 40). Moreover, she has had a positive influence on Wariinga who no doubt emulates her in what might be called her second birth. Wangari does not subordinate her actions to those of men, she spurs them to act. She pairs with Wariinga to fulfill Ngugi's declared will to create strong female characters in his own way, although Wariinga's killing act adds further complexity to an already dynamic creation. In comparison to Wanja and Wariinga, Wangari stands as a character that does not opt for a single-handed resolution of her plight but chooses to lean on and act with the people. More than a transitional figure linking the old and the new generations of woman, Wangari prefigures the new type of woman, which Wariinga in Devil on the Cross embodies. Wariinga stands as a prototype of Ngugi's contemporary women who are not to be confined in crippling gender roles once their consciousness has been raised. The seeds of her portraiture were already showing in Petals of Blood through the androgynous features of the freedom-fighter represented in a wood sculpture. Nyakinyua's comment, in this respect, reasserts the need for men and women to unite and stand in the fight against the oppressor class: "a man cannot have a child without a woman. A woman cannot bear a child without a man. And was it not a man and a woman who fought to redeem this country?" (Petals 161). This recalls Gikonyo's creative project in A Grain of Wheat that emphasizes Ngugi's concept of the complementary role of man and woman in the struggle:

He would now carve a thin man, with hard lines on his face, shoulders and head bent, supporting the weight. His right hand would stretch to link with that of a woman, also with hard lines on her face. The third figure would be that of a child on whose head or shoulders the two hands of the man and woman would meet.

(Grain of Wheat 279)

In Matigari, Guthera appears at the moment when Matigari, in search of the truth, realizes that he should have started looking for women, "the ones who uphold the flame of continuity and change in the homestead" (Matigari 27). As Guthera puts it, her life has been dominated by men, "be they our father in heaven, my father on earth, the priest, or all men who have bought my body" (Matigari 140). Hers, like Penda's and Wanjas, are experiences that textualize Nfah-Abbenyi's notion of "women's bodies and sexualities as contested terrains where power struggles and control are played out within preestablished hierarchies and gender relations" (Nfah-Abbenyi 72). But Guthera can choose to give herself freely for an end she believes in. She breaks a vow, that is, never to sleep with a policeman, which she calls her eleventh commandment, to rescue Matigari, the "patriot who survived the bullets" (20). As the story unfolds, Guthera develops 
into an agent who means to change "whatever it is that makes people live like animals, especially women." Thus, she shoulders the burden of awareness:

Is it enough for me just to say that now I know? ... What can we as women do to change our lives? Or will we continue to follow the paths carved out for us by men? Aren't we in the majority anyway? Let's go! From now on I want to be in the vanguard. I shall never be left behind again. (Matigari 140)

As a result, she engages in the struggle against the foreign and the national oppressors alongside Matigari. They disappear together, chased by police hounds. Their disappearance is a mystery like Matigari himself. They are expected to emerge from the forest again and join force with the homeless young people like their friend Muriuki, one of the derelict children living in the "vehicle cemetery." Their return is going to be different from Matigari's who laid down arms believing that the war for independence was over, and came out of the forest with the gird of peace. In this regard, Ijeoma C. Nwajiku's comment aptly describes the prevailing vision:

In the African woman's quest for a positive and wholesome definition of womanhood and empowerment, the African male is not excluded. So that despite the diverse perspectives represented by the multiple theories of female consciousness currently making their runs on the African literary scene, one idea remains poignant: the struggle includes the survival of the female as well as the male. (Nwajiku 56)

Guthera and Matigari are constituents of the writing project Ngugi expounds in Writers in Politics: an undertaking that reflects "the reality of the African struggle against colonial domination" and against "the messenger class: the neocolonial native ruling elite" (29). "Such a literature," Ngugi writes, "again at its critical best and most committed, defines a people not in terms of always being acted on but in terms of actors" (Writers in Politics 30).

Considering the treatment of female characters by Sembene and Ngugi, it clearly appears that both novelists write from a marked progressive ideological point of view. There results the emphasis they put on the predicament of underprivileged women configured by Penda and Guthera, who side with the people and strive to be at the vanguard of the struggle for social justice. The educated women like Tioumbé and Wariinga are in the same way actively involved in their communities' war against oppressive forces. They maintain close ties with the masses of people; accordingly their struggle for freedom is part of the general liberation process in which their societies are engaged. Their creation partakes of certain male writers' will to share in the making of a meliorative definition of African womanhood. Although the male writers' efforts may be variously assessed by female critics, they have nonetheless articulated figures of women that differ from the Manichean vision of female subjects often found in fiction written by men. Theirs is a form of writing that takes women out of the liminal bounds and draws them into the centre of the public sphere. This trend 
is growing, as it is given momentum by the amount of criticism from female creative and reflective writers. More and more male creative writers are striving to draw portraits of women from an increasingly subdued androcentric perspective. Similarly, more male critics are venturing into the female creative space and are cautiously foraying further into it, mindful of the insider/outsider location and of the critical attention of their female colleagues. The on-going debate among female and male writers and critics is significantly enhancing African literature.

\section{Omar SOUGOU, Works Cited Université Gaston Berger, Senegal}

Brown, Lloyd. Women Writers in Black Africa. Connecticut: Greenwood Press, 1981.

DAvies, Carole Boyce. "Maidens, Mistresses and Matrons: Feminine Images in Selected Soyinka Works." Ngambika: Studies of Women in African Literature. Ed. C. B. Davies and Anne Adams Graves. Trenton, New Jersey: Africa World Press, 1986. 75-88.

Kramarae, Cheris and Paula A. Treichlern, eds. A Feminist Dictionary. London: Pandora Press, 1985.

LitTLE, Kenneth. The Sociology of Urban African Women's Image in African Literature. London: Macmillan, 1980.

Mugo, Micere Githae. "Interview." In Their Own Voices: African Women Writers Talk. Ed. Adeola James. London: James Currey, 1990.

Nғaн-Aвbenyi, Juliana Makuchi. Gender in African Women's Writing: Identity, Sexuality, and Difference. Bloomington: Indiana U P, 1997.

Ngugi wa Thiong'o. Matigari. London: Heinemann, 1989.

—. Barrel of a Pen, London: New Beacon Books, 1983.

—. Devil on the Cross. London: Heinemann, 1982.

—. Detained: A Writer's Prison Diary. London: Heinemann, 1981.

—. Writers in Politics: Essays. London: Heinemann, 1981.

-. Petals of Blood. London: Heinemann, 1977.

-. A Grain of Wheat. London: Heinemann, 1967.

NwajIaku, Ijeoma C. "Representations of the Womanist Discourse in the Short fiction of Akachi Ezeigbo \& Chinwe Okechukwu." New Women's Writing in African Literature. ALT 24. Oxford: James Currey, 2004. 55-68.

Ogunyemi, Chikwenye Okonjo. "Women in Nigerian Literature." Perspectives on Nigerian Literature: 1700 to the Present. Vol. I. Lagos: Guardian Books, 1988. 60-67.

Schipper, Mineke. "Mother Africa on a Pedestal: The Male Heritage in African Literature and Criticism." Women in African Literature Today, ALT 15. London: James Currey 1987. 35-54.

Sembene, Ousmane. God's Bits of Wood. Trans. Francis Price. London: Heinemann, [1960]. 1969. 
—. L'Harmattan. Paris: Présence africaine, [1964], 1980.

Smiley-Wallace, Karen, "Women and Alienation: Analysis of the Works of Two

Francophone African Novelists." Ngambika. Ed. C. B. Davies and Anne Adams Graves. (63-73).

Soyinka, Wole. The Interpreters. London: Heinemann, 1967.

Stratton, Florence. Contemporary African Literature and the Politics of Gender. London: Routledge, 1994.

Watchel, Eleanor. "The Mother and the Whore: Image and Stereotype of African Women.” Umoja, 1, no.2 (1977), 31-48. 